\title{
Pengaruh Asam Sitrat, Aluminium, dan Interaksinya Terhadap Pertumbuhan Kecambah Jagung Hibrida (Zea mays L.) Varietas Bisi- 18
}

\section{Effect of Citric Acid, Aluminum, and its Interaction on Seedling Growth of Hibrida Maize (Zea mays L.) Var. Bisi-18}

\author{
Wina Safutri1 $^{*}$, Zulkiflii $^{2)}$, dan Tundjung Tripeni Handayani ${ }^{2)}$ \\ ${ }^{1}$ Mahasiswa Jurusan Biologi, FMIPA Universitas Lampung \\ ${ }^{2}$ Dosen Jurusan Biologi, FMIPA Universitas Lampung \\ Jl. Soemantri Brojonegoro No. 1, Bandar Lampung, Lampung, Indonesia, 35145 \\ *e-mail : wsafutri@yahoo.com
}

\begin{abstract}
The objective of this research was to know effect of citric acid, aluminum, and their its interaction on the seedling growth of hibrida maize (Zea mays L.) Var. Bisi-18. The experiment was conducted during January 2016 in Plant Physiology Laboratory, Department of Biology, Faculty of Mathematics and Natural Science, University of Lampung. The experiment was implemented in $2 \times 3$ factorial experiments. Factor A was Aluminum with 2 levels: $0 \mathrm{mM}, 5 \mathrm{mM}$. Factor B was Citric Acid with 3 levels: $0 \mathrm{mM}, 5 \mathrm{mM}$, and $10 \mathrm{mM}$. After selected corn seeds were soaked in citric acid solution for 24 hours, and germinated in plastic tray. After 7 days seedlings were planted in plastic containers that contain aluminum solution. Variables in this research were shoot length, seedling fresh weight, shoot root ratio, and relative water content after 7 days of growing period. Analysis of variance was conducted at 5\% significant level. If interactions between aluminum and citric acid was not significant, main effect was determined at 5\% significant level with LSD test. If interactions between aluminum and citric acid was significant, simple effect was determined at 5\% significant level with $F$ test. The result showed that no aluminum effect observed on all variables, and citric acid affected negativly all variables. No interctions between aluminum and citric acid on all seedling growth variables of maize hibrida Var. Bisi-18. It is concluded aluminum 5mM was not able to cause stress in maize seedling. In no stress condition citric acid has negative effect on maize seedling growth.
\end{abstract}

Keyword: Citric acid, Aluminium, Maize Seedling, Shoot Length, Seedling Fresh Weight.

Diterima : 12 Juni 2016, disetujui 27 Agustus 2016

\section{PENDAHULUAN}

Tanaman jagung merupakan sumber pangan penting setelah padi. Selain sebagai sumber pangan juga sebagai bahan baku pakan ternak, pemanis pengganti gula tebu, bahan baku pembuat biofuel, bahan baku pembuat plastik dan lain-lain. Propinsi penghasil jagung terbesar di Indonesia adalah Jawa Timur, Jawa Tengah, Lampung, Sulawesi Selatan dan Nusa Tenggara Timur (Sarasutha, 2002).

Pertambahan jumlah penduduk dan peningkatan pendapatan turut meningkatkan kebutuhan makanan yang bernilai gizi tinggi seperti jagung. Peningkatan kebutuhan jagung di Indonesia berkaitan erat dengan perkembangan industri pangan seperti meningkatnya produk olahan atau bahan setengah jadi, seperti bahan 
campuran pembuatan kue, bubur instan campuran kopi dan produk minuman rendah kalori sehingga konsumsi jagung per kapita mencapai $15 \mathrm{~kg}$. Selain itu, perkembangan industri konsumsi pakan di Indonesia mencapai $25 \mathrm{~kg}$ per kapita. Bahan baku pakan ternak sekitar 50\% berasal dari jagung sehingga untuk memenuhi kebutuhan pangan maupun pakan, Indonesia masih mengimpor sekitar 2 juta ton jagung pada tahun 2002 (Suprapto, 2002).

Beberapa varietas jagung hibrida yang beredar di pasaran seperti Bisi 2, Bisi 16, Bisi 18, NK 22, NK 33, Pionir, Semar dan lain sebagainya. Panen jagung hibrida muda sangat diminati di lapangan, karena umurnya pendek, pemasarannya cukup lancar. Kebutuhan akan produksi jagung terus meningkat setiap tahunnya maka perlu adanya pengelolaan dalam produksi jagung seperti penggunaan benih yang unggul dan areal tanaman yang cukup luas.

Pada tahun 2002, luas areal tanaman jagung mencapai 3.291.616 hektar dengan daerah produksi di Jawa Timur, Jawa Tengah, Sulawesi Selatan, dan Nusa Tenggara. Di pulau Jawa memiliki areal yang terluas dalam penanaman jagung yaitu sekitar 62\% dari total seluruhnya (Suprapto, 2002). Namun, perluasan areal pertanaman pada areal bukaan baru sering menghadapi faktor pembatas ekologi, antara lain, tingginya tingkat kemasaman dan kandungan Aluminium (Al) tanah. Kandungan Al yang tinggi dapat mengganggu pertumbuhan jagung dan merusak perakaran tanaman sehingga mengakibatkan tidak efisiennya akar menyerap unsur hara dan air (Ma et al., 2000).

Asam organik diketahui berperan dalam mekanisme ketahanan tumbuhan terhadap cekaman $\mathrm{Al}$. Asam sitrat merupakan asam organik lemah yang mempunyai rumus kimia $\mathrm{C}_{6} \mathrm{H}_{8} \mathrm{O}_{7}$ (Sarulli dan Damayanti, 2010). Menurut Abdullahi et al (2006) asam sitrat $5 \mathrm{mM}$ tidak berpengaruh terhadap pertumbuhan kecambah kedelai dalam ketiadaan aluminium. Pada Al $2 \mathrm{mM}$ dan $5 \mathrm{mM}$ nampaknya asam sitrat hanya memperbaiki toksisitas aluminium, mengakibatkan pertumbuhan kecambah kedelai dengan meningkatkan panjang hipokotil, panjang kecambah dan panjang akar kecambah.

Tujuan penelitian ini untuk mengetahui efek perendaman benih jagung hibrida varietas Bisi-18 dalam larutan asam sitrat terhadap pertumbuhan kecambah jagung dan efek pemberian aluminium pada kecambah terhadap pertumbuhan kecambah jagung hibrida varietas Bisi-18.

\section{METODE}

Penelitian ini telah dilaksanakan di Laboratorium Fisiologi Tumbuhan, Jurusan Biologi, Fakultas Matematika dan Ilmu Pengetahuan Alam, Universitas Lampung dari bulan Januari - Februari 2016.

Penelitian ini dilakukan dalam percobaan faktorial 2x3. Faktor A adalah Aluminium dengan 2 taraf konsentrasi $\mathrm{Al}(\mathrm{OH})_{3}: 0 \mathrm{mM}$ dan $5 \mathrm{mM}$. Faktor B adalah asam sitrat dengan 3 taraf konsentrasi ; $0 \mathrm{mM}, 5$ $\mathrm{mM}$, dan 10mM. Setiap kombinasi perlakuan diulang 5 kali.

Variabel dalam penelitian ini adalah panjang tunas, berat segar kecambah, kadar air relatif, rasio tunas akar. Parameter dalam penelitian ini adalah nilai tengah $(\mu)$ dari semua variabel tersebut.

Seleksi benih dilakukan dengan merendam benih dalam akuades selama 10 menit. Benih jagung yang mengapung dan sampah dibuang, sedangkan benih yang tenggelam diambil untuk dikecambahkan. Benih yang telah diseleksi selanjutnya direndam dalam 3 konsentrasi larutan asam sitrat yaitu $0 \mathrm{mM}, 5 \mathrm{mM}$, dan 10 $\mathrm{mM}$ selama 24 jam. Benih jagung yang telah direndam dalam larutan asam sitrat dikecambahkan dalam 3 nampan plastik yang telah dilapisi dengan kapas dan dibasahi dengan akuades. Setiap nampan berisi 100 butir benih jagung.

Benih yang telah berkecambah dipindahkan kedalam gelas plastik yang telah dilapisi dengan kapas ; 2 kecambah setiap gelas plastik. Kapas dibasahi dengan larutan $\mathrm{Al}(\mathrm{OH})_{3}$. Pengamatan variabel pertumbuhan kecambah dilakukan 7 hari setelah penanaman. 
Safutri, W dkk : Pengaruh Asam Sitrat, Aluminium, dan Interaksinya Terhadap Pertumbuhan Kecambah Jagung...

Panjang tunas diukur dari pangkal batang sampai ujung batang dengan penggaris dan dinyatakan dalam sentimeter $(\mathrm{cm})$. Akar dipisahkan dari tunas (batang + daun). Akar dan tunas ditimbang dengan neraca analitik dan dinyatakan dalam gram. Berat segar kecambah adalah berat segar akar + berat segar tunas. Kadar air relatif kecambah ditentukan menurut Yamasaki dan Dillenburg (1999) dengan rumus : Kadar air relative sama dengan Berat segar kecambah dikurangi berat kering kecambah di bagi berat segar kecambah dikalikan seratus persen.

Rasio tunas akar ditentukan menurut Yuliana dkk (2013) berdasarkan rumus : Rasio Tunas Akar sama dengan Berat segar tunas batang di tambah berat segar tunas daun di bagi berat segar akar.

Data dianalisis ragam pada taraf nyata $5 \%$ dan jika interaksi antara faktor A dan faktor B tidak nyata maka dilanjutkan dengan penentuan main effect faktor A dan faktor B dengan uji BNT pada taraf nyata 5\%, dan jika interaksi nyata maka dilanjutkan dengan penentuan simple effect faktor A dengan uji $\mathrm{F}$ pada taraf nyata $5 \%$.

\section{HASIL DAN PEMBAHASAN}

Panjang tunas. Analisis ragam menunjukkan bahwa asam sitrat berpengaruh nyata terhadap panjang tunas, sedangkan aluminium tidak.Interaksi antara aluminium dan asam sitrat tidak berpengaruh nyata terhadap panjang tunas (Tabel 1).

Tabel 1. Panjang Tunas Kecambah Jagung Hibrida Varietas Bisi-18

\begin{tabular}{cccc}
\hline Asam Sitrat $(\mathrm{mM})$ & Kontrol & Aluminium & Nilai Tengah \\
\hline 0 & $24,80 \pm 3,93$ & $23,78 \pm 4,22$ & $24,29^{\mathrm{a}}$ \\
5 & $11,28 \pm 3,99$ & $15,48 \pm 3,69$ & $13,38^{\mathrm{b}}$ \\
10 & $14,98 \pm 3,75$ & $16,20 \pm 6,01$ & $15,59^{\mathrm{b}}$ \\
\hline
\end{tabular}

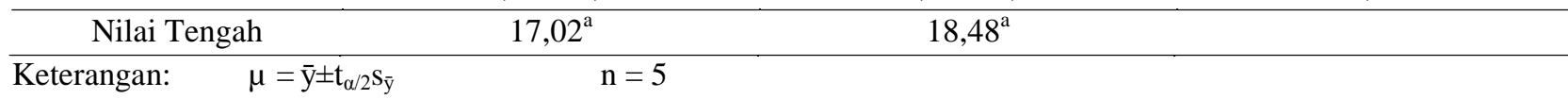

BNT $0,05=4,46$

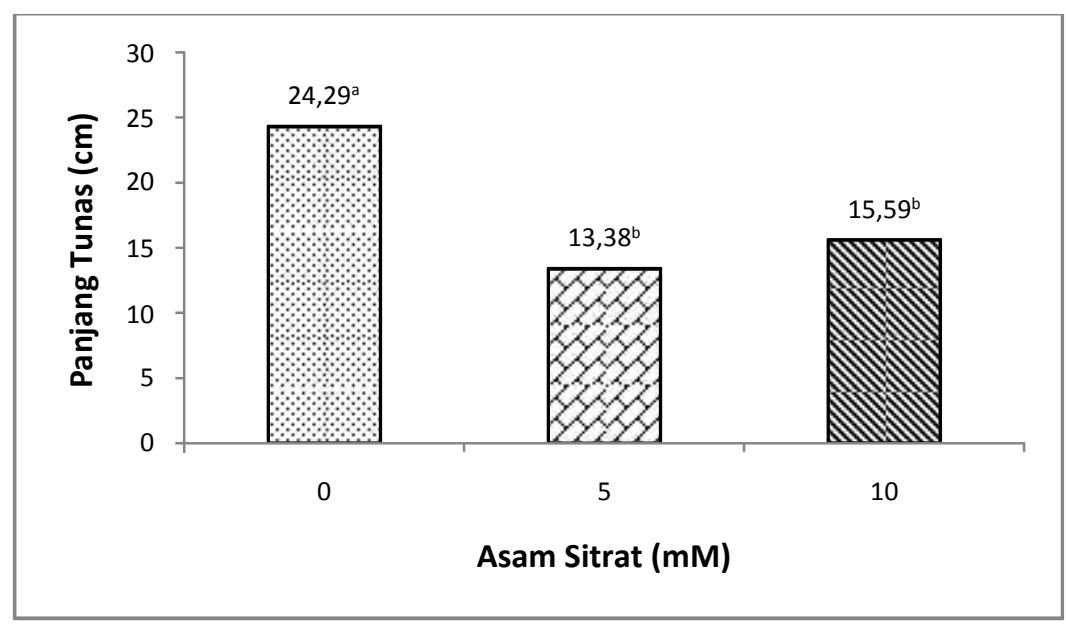

Gambar 1. Grafik Main Effect Asam Sitrat Terhadap Panjang Tunas

Berat segar kecambah. Analisis ragam menunjukkan bahwa asam sitrat berpengaruh nyata terhadap berat segar, sedangkan aluminium tidak. Interaksi antara aluminium dan asam sitrat tidak berpengaruh nyata terhadap berat segar kecambah (Tabel 2). 
Jurnal Penelitian Pertanian Terapan

Kadar air relatif. Analisis ragam menunjukkan bahwa asam sitrat berpengaruh nyata terhadap kadar air relatif, sedangkan aluminium tidak. Interaksi antara aluminium dan asam sitrat tidak berpengaruh nyata terhadap kadar air relative (Tabel 3).

Tabel 2. Berat Segar Kecambah Jagung Hibrida Varietas Bisi-18

\begin{tabular}{cccc}
\hline Asam Sitrat $(\mathbf{m M})$ & Kontrol & Aluminium & Nilai Tengah \\
\hline $\mathbf{0}$ & $0,909 \pm 0,089$ & $0,837 \pm 0,0305$ & $0,873^{\mathrm{a}}$ \\
$\mathbf{5}$ & $0,564 \pm 0,098$ & $0,666 \pm 0,127$ & $0,615^{\mathrm{b}}$ \\
$\mathbf{1 0}$ & $0,608 \pm 0,115$ & $0,896 \pm 0,201$ & $0,752^{\mathrm{ab}}$ \\
\hline
\end{tabular}

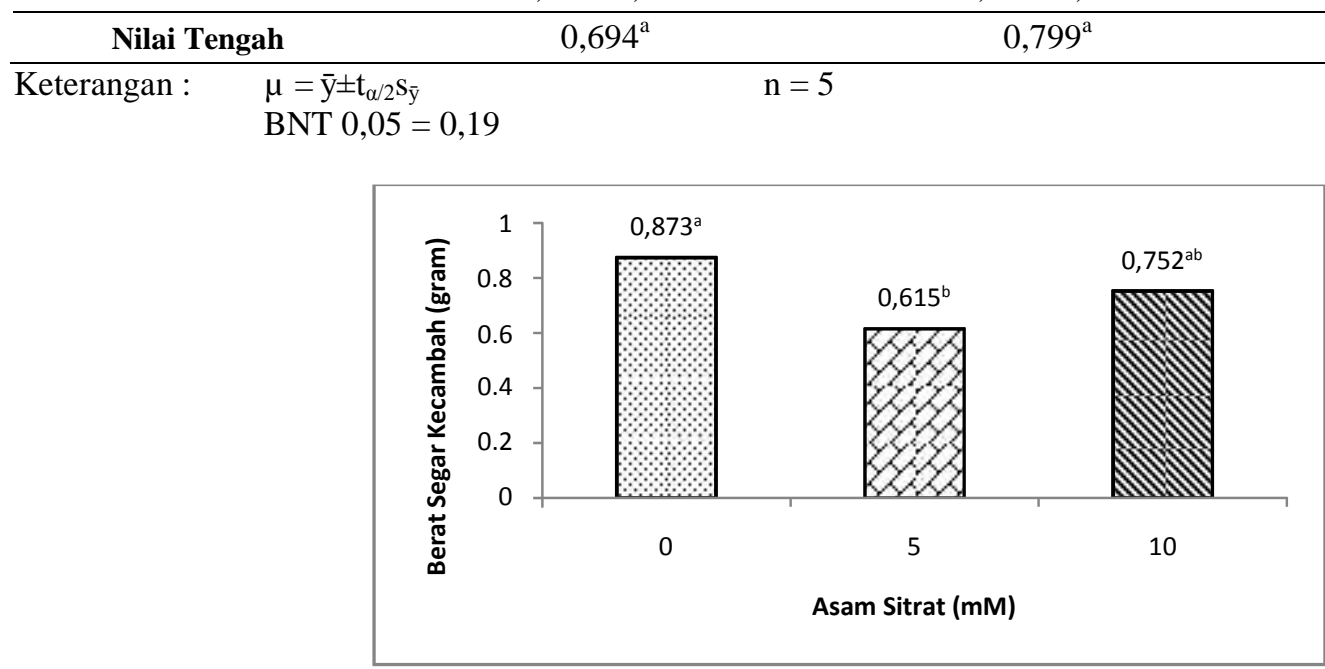

Gambar 2. Grafik Main Effect Asam Sitrat Terhadap Berat Segar Kecambah

Tabel 3. Kadar Air Relatif Kecambah Jagung Hibrida Varietas Bisi-18

\begin{tabular}{cccc}
\hline Asam Sitrat $(\mathrm{mM})$ & Kontrol & Aluminium & Nilai Tengah \\
\hline 0 & $81 \pm 1,64$ & $80,6 \pm 5,02$ & $80,8^{\mathrm{a}}$ \\
5 & $73,6 \pm 5,21$ & $73,6 \pm 6,46$ & $73,6^{\mathrm{b}}$ \\
10 & $73,2 \pm 5,86$ & $82,4 \pm 2,88$ & $77,8^{\mathrm{ab}}$ \\
\hline Nilai Tengah & $75,93^{\mathrm{a}}$ & $78,87^{\mathrm{a}}$ &
\end{tabular}

Keterangan : $\quad \mu=\overline{\mathrm{y}} \pm \mathrm{t}_{\alpha / 2} \mathrm{~S}_{\overline{\mathrm{y}}} \quad \mathrm{n}=5$

BNT $0,05=5,41$

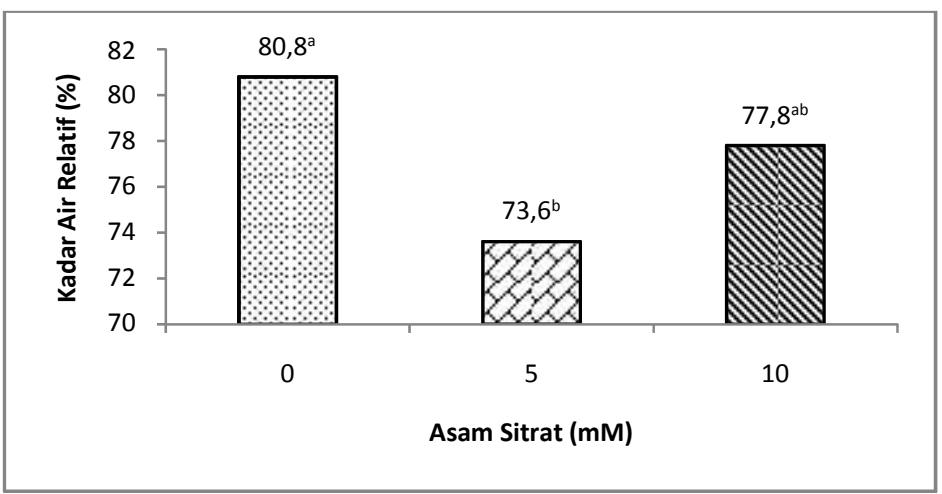

Gambar 3. Grafik Main Effect Asam Sitrat Terhadap Kadar Air Relatif

Rasio tunas akar. Analisis ragam menunjukkan bahwa asam sitrat berpengaruh nyata terhadap rasio tunas akar, sedangkan aluminium tidak. Interaksi antara aluminium dan asam sitrat tidak berpengaruh nyata terhadap rasio tunas akar (tabel 4). 
Safutri, W dkk: Pengaruh Asam Sitrat, Aluminium, dan Interaksinya Terhadap Pertumbuhan Kecambah Jagung...

Tabel 4. Rasio Tunas Akar Jagung Hibrida Varietas Bisi-18

\begin{tabular}{cccc}
\hline Asam Sitrat $(\mathrm{mM})$ & Kontrol & Aluminium & Nilai Tengah \\
\hline 0 & $0,71 \pm 0,21$ & $0,63 \pm 0,18$ & $0,67^{\mathrm{a}}$ \\
5 & $0,40 \pm 0,12$ & $0,35 \pm 0,05$ & $0,38^{\mathrm{b}}$ \\
10 & $0,60 \pm 0,19$ & $0,49 \pm 0,21$ & $0,54^{\mathrm{ab}}$ \\
\hline Nilai Tengah & $0,57^{\mathrm{a}}$ & $0,49^{\mathrm{a}}$ & \\
\hline
\end{tabular}

Keterangan : $\quad \mu=\bar{y} \pm t_{\alpha / 2} S_{\bar{y}} \quad n=5$

BNT $0,05=0,17$

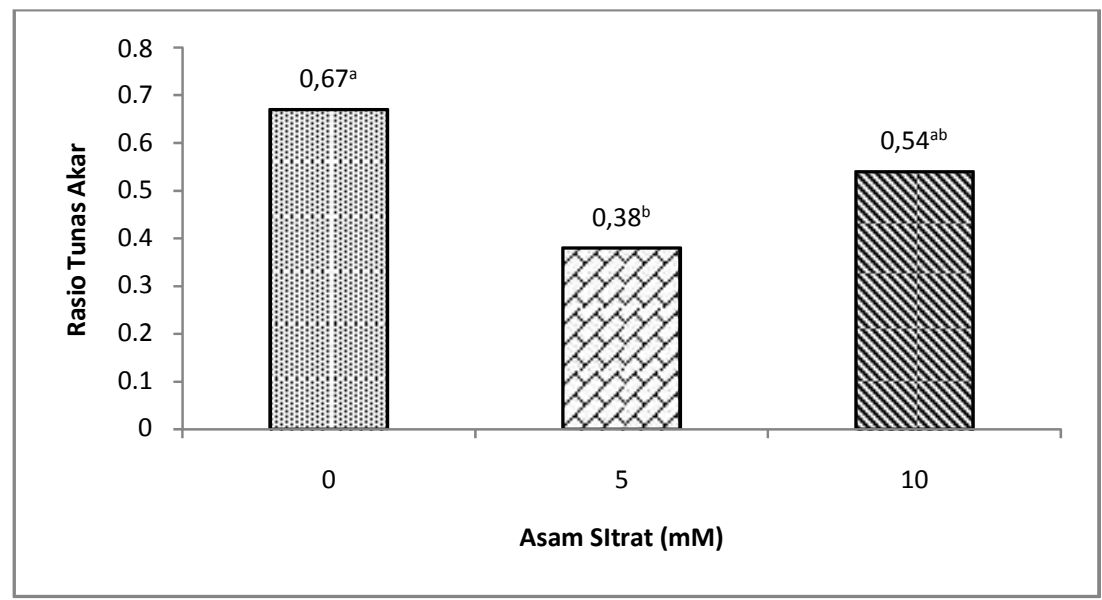

Gambar 4. Grafik Main Effect Terhadap Rasio Tunas Akar

Efek perendaman benih jagung hibrida varietas Bisi-18 dalam larutan asam sitrat dan efek pemberian aluminium pada kecambah terhadap semua variabel pertumbuhan kecambah dapat dilihat pada tabel 5 .

Tabel 5. Efek Asam Sitrat dan Aluminium terhadap Semua Variabel Pertumbuhan Kecambah Jagung Hibrida Varietas Bisi-18

\begin{tabular}{|c|c|c|c|}
\hline Variabel & Asam Sitrat & Aluminium & Interaksi \\
\hline Panjang Tunas & & - & - \\
\hline Berat Segar Kecambah & & - & - \\
\hline Kadar Air Relatif & & - & - \\
\hline Rasio Tunas Akar & & - & - \\
\hline
\end{tabular}

Hasil penelitian menunjukkan bahwa perendaman benih jagung hibrida varietas Bisi-18 dalam larutan asam sitrat $5 \mathrm{mM}$ dan $10 \mathrm{mM}$ berefek negatif terhadap semua variabel pertumbuhan kecambah. Panjang tunas mengalami penurunan sebesar $44,91 \%$, berat segar kecambah mengalami penurunan sebesar $29,55 \%$, kadar air relatif mengalami penurunan sebesar $8,91 \%$, dan rasio tunas akar mengalami penurunan sebesar $43,28 \%$.

Pemberian aluminium pada kecambah tidak memiliki efek terhadap semua variabel pertumbuhan kecambah jagung hibrida varietas Bisi-18. Demikian juga interaksi antara asam sitrat dan aluminium tidak berpengaruh terhadap semua variabel pertumbuhan kecambah.

Analisis proporsi akar dan tunas (Gambar 5) menunjukkan bahwa asam sitrat mengubah proporsi akar dan tunas dengan meningkatkan proporsi akar dan menurunkan proporsi tunas. Pada keadaan defisit air tanaman mengalokasikan lebih banyak fotosintat untuk pertumbuhan akar sehingga rasio tunas akar menjadi lebih kecil (Taiz \& Zeiger, 1991). Perendaman benih jagung dalam larutan asam sitrat mendorong alokasi cadangan makanan dari endosperm jagung lebih banyak untuk pertumbuhan akar. Oleh sebab itu terjadi 


\section{Jurnal Penelitian Pertanian Terapan}

penurunan alokasi cadangan makanan dari endosperm jagung untuk pertumbuhan tunas. Akibatnya pertumbuhan kecambah dalam hal ini berat segar dan panjang tunas mengalami penurunan.

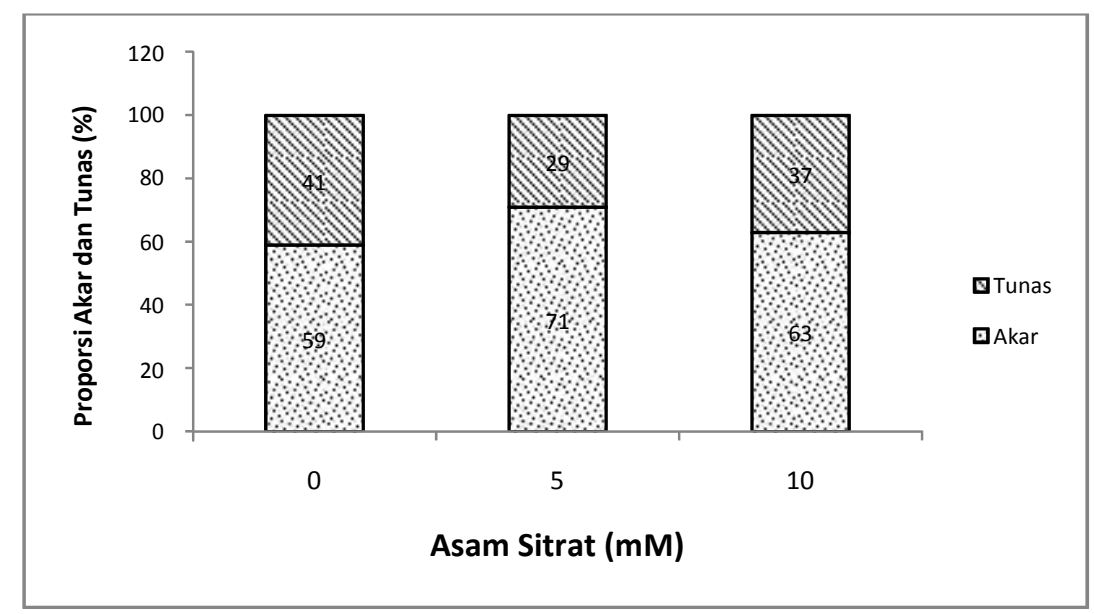

Gambar 5. Proporsi Akar dan Tunas Kecambah Jagung Hibrida Varietas Bisi-18dengan perlakuan alumunium

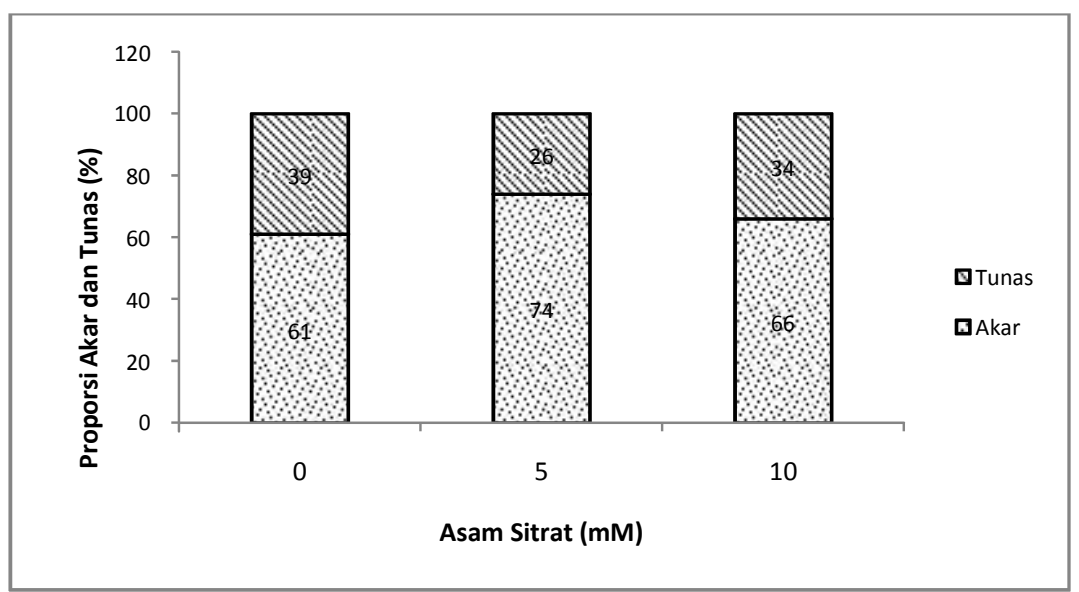

Gambar 6. Proporsi Akar dan Tunas Jagung Hibrida Varietas Bisi-18 dengan perlakuan alumunium

Pemberian aluminium mendorong lebih banyak lagi alokasi cadangan makanan dari endosperm untuk pertumbuhan akar sehingga menurunkan pertumbuhan tunas (Gambar 6). Menurut Sivaguru et al (1991) gejala keracunan aluminium yang paling mudah dapat dilihat adalah penghambatan pertumbuhan akar.

Analisis proporsi bahan kering dan air menunjukkan bahwa asam sitrat mengubah proporsi bahan kering dan air dengan menurunkan proporsi air (Gambar 7). Oleh sebab itu, efek negatif asam sitrat terhadap pertumbuhan kecambah adalah mengurangi kemampuan kecambah untuk menyerap air.

Hasil penelitian ini berbeda dari Abdullahi et al (2006) pada kecambah kedelai. Pada $2 \mathrm{mM} \mathrm{Al}$ asam sitrat mengurangi cekaman aluminium dengan meningkatkan berat segar sampai $8 \%$ tapi tidak memiliki efek terhadap berat kering. Pada $5 \mathrm{mM} \mathrm{Al}$ asam sitrat meningkatkan secara nyata berat segar sampai $12 \%$. Perbedaan ini menunjukkan respon yang berbeda antara jagung hibrida varietas Bisi-18 dengan kedelai terhadap cekaman aluminium (Gambar 8). Jagung hibrida varietas Bisi-18 lebih resisten terhadap aluminium dibandingkan dengan kedelai. 
Safutri, W dkk: Pengaruh Asam Sitrat, Aluminium, dan Interaksinya Terhadap Pertumbuhan Kecambah Jagung...

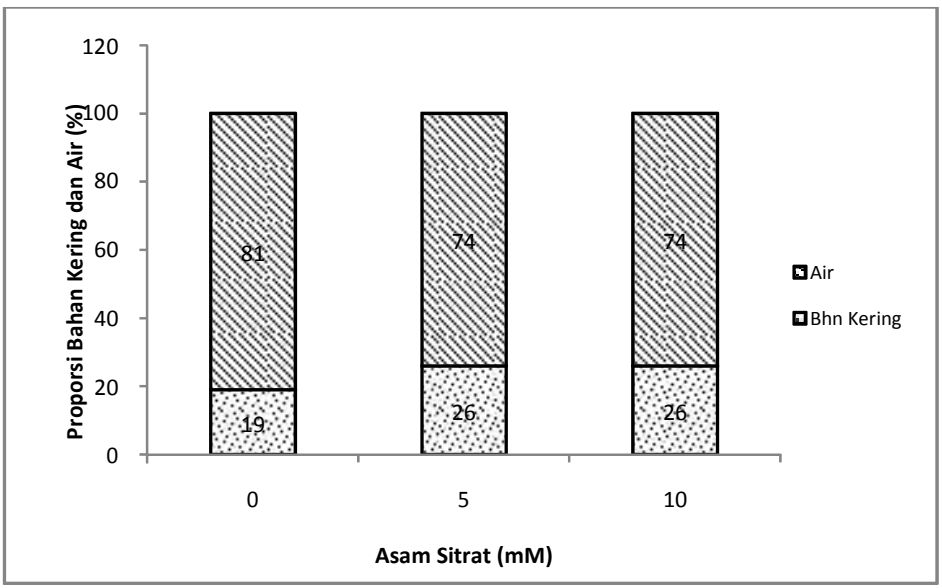

Gambar 7. Proporsi bahan kering dan air pada kecambah jagung hibrida varietas bisi-18 dengan perlakuan kontrol

Abdullahi et al (2006) juga melaporkan bahwa asam sitrat sendiri tidak berpengaruh terhadap pertumbuhan kecambah kedelai dalam ketiadaan aluminium.Asam sitrat memperbaiki toksisitas aluminium sehingga mempertahankan pertumbuhan kecambah kedelai.

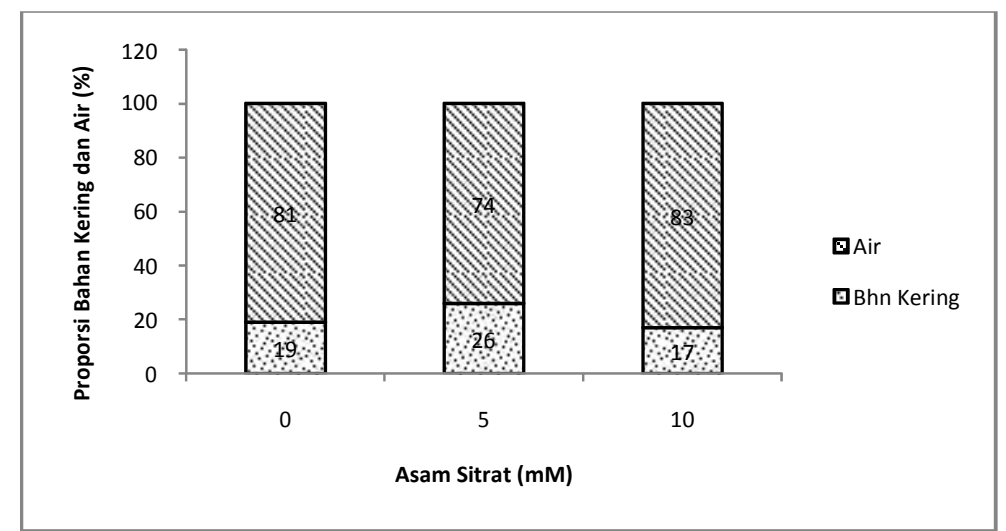

Gambar 8. Proporsi bahan kering dan air pada kecambah jagung hibrida varietas bisi-18 dengan perlakuan alumunium

Pemberian aluminium pada kecambah relatif tidak mengubah proporsi bahan kering dan air kecambah jagung hibrida varietas Bisi-18.

\section{KESIMPULAN}

Kesimpulan yang diperoleh pada penelitian ini adalah perlakuan $5 \mathrm{mM}$ aluminium tidak menimbulkan cekaman terhadap kecambah jagung hibrida varietas Bisi-18; Perendaman benih jagung dalam larutan asam sitrat (5 dan $10 \mathrm{mM}$ ) menurunkan semua variabel pertumbuhan kecambah jagung hibrida varietas Bisi-18; Kecambah jagung hibrida varietas Bisi-18 resisten terhadap aluminium 5mM.

\section{SARAN}

Perlu dilakukan penelitian dengan menggunakan konsentrasi aluminium yang lebih tinggi untuk menimbulkan cekaman aluminium pada kecambah jagung hibrida varietas Bisi-18. 


\section{DAFTAR PUSTAKA}

Abdullahi, B.A. Huang, P. Bao, D.P. Xiao-Ying. Bao-Hua Jiang.Jie Zhu. Heng-Guan Shen\&Yong-Hua Yang. 2006. Effects of Citric Acid On Soybeans Seedling Growth Under Aluminum Stress. Jurnal of Plant Nutrition. $2: 367-375$.

Ma, J.F., S. Taketa, Z.M. Yang. 2000. Al tolerance genes on the short arm of chromosome 3R are linked to organic acid release in tricale. Plant Physiol. 122:687-694.

Sarasutha.IG.P. 2002.Kinerja Usaha Tani dan Pemasaran Jagung di Sentra Produksi.Jurnal Litbang Pertanian, 21(2). p. 39-47.

Sivaguru, M., B. Fransitisck, V. Dieter, H.F. Huber, \& J.H. Walter. 1999. Impacts of aluminium on thecytoskeleton of the maize root apex. Short termeffects on the distal part of the transition zone.Plant Physiol. 199: 1073 - 1082.

Suprapto, H.S., 2002. Bertanam Jagung. Penebar Swadaya. Jakarta

Taiz L and Zeiger E. 1991.Plant Physiology. Tokyo. The Benyamin/Cumming Publishing Company Inc. p: 219-247.

Yamasaki, S and Dillenburg, L.R. 1999. Measurement Of Leaf Relative Water Content. In Araucaria Angustifolia.Revista Brasileira de Fisiologia. Vegetal, 11 (2), 69-75

Yuliana, N., Ermavitalini. D., dan Agisimanto, D., 2013. Efektivitas Metapolin (Mt) dan NAA Terhadap Pertumbuhan In VitroStroberi (Fragarla ananassa Var. Dorit) Pada Media MS Cair dan Ketahanannya di Media Aklimatisasi. Jurnal Sains dan Seni Pornits Vol. 2 